\title{
The experience of military surgeons from a north Afghanistan deployment and lessons for the future
}

\author{
Kuzey Afganistan'da konuşlandırılan askeri cerrahların deneyimi ve \\ gelecek için dersler
}

\author{
Stavros GOURGIOTIS, ${ }^{1}$ Roland SCHMIDT ${ }^{2}$
}

\begin{abstract}
A military surgeon is a physician who works in a standard clinical field, but who also has to learn to adapt his skills to exceptional circumstances and must cope with special challenges due to his deployment in crisis regions, a fact that is one of the major factors influencing military medical strategy planning. The only certainty is that these special circumstances differ fundamentally from the routine circumstances at the military hospitals of the mother country. The limitations in personnel, equipment and technical resources, the isolation within the deployment region, the lack of a local healthcare system, the specialized aspects of the patients, and the nature of the injuries and diseases represent the main unique challenges.
\end{abstract}

Key Words: Combat; casualty; care; military; surgeon.
Askeri cerrah, standart bir klinik alanda çalışan ancak aynı zamanda becerilerini olağan dışı durumlara adapte etmeyi öğrenmek zorunda olan ve askeri tıbbi strateji planlamas1nı etkileyen başlica faktörlere ve kriz bölgelerinde mevzisine bağlı güçlüklerle baş etmek zorunda bulunan bir doktordur. Tek kesin olan şey, bu özel koşulların temelde anavatanın askeri hastanelerindeki rutin koşullardan farklılık göstermesidir. Personel, ekipman ve teknik kaynaklardaki k1sıtlılıklar, mevzi bölgesindeki yalıtım, yerel bir sağlık sisteminin olmaması, hastaların özel durumları ile yaralanma ve hastalıkların doğası, başlıca benzersiz zorluklardır.

Anahtar Sözcükler: Savaş; yaralı; bakım; askeri; cerrah.
Since the mid-19th century, Afghanistan had been important to outside powers when it became a buffer state in the struggle for territory between the British and Russian empires. Following the Soviet invasion in 1979 and the 10-year Soviet occupation, the country endured civil war, Taliban rule and war with the United States and its coalition forces. The country was left in total disarray. This instability and insecurity resulted in a very low life expectancy (44 years) and an annual mortality of 20 per 1,000 residents. $^{[1]}$

The health services in Afghanistan remain in an alarming condition. An inadequate number of medic and paramedic personnel are available to provide medical care, especially in rural and remote areas. Furthermore, the work in public services is paid inadequately, much lower than in private practice or employment with the aid organizations, while the quality standards of hospital provision are very low and the ratio of hospital beds to the national population figures is inadequate.

In Afghanistan, the role of the medical personnel of the International Security Assistance Force (ISAF) nations is to provide medical service support to the ISAF personnel deployed, to support the development of the medical services of Afghan military forces and police, to participate in the provision of services to the civilian population - a policy known as 'winning hearts and minds' - as well as to support the development of the civilian health services.

The following contribution is based on our experience during our deployment from July to November 2009 as military surgeons at the role II military hospital of Provincial Reconstruction Team (PRT) Kunduz. Ulm, Almanya. 


\section{The German Role II Military Hospital in the Provincial Reconstruction Team (PRT) of Kunduz}

PRTs in Afghanistan are small, civilian-military units that assist provincial and local governments to govern more effectively and deliver essential services. ${ }^{[2]}$ The role II military hospital in the German PRT of Kunduz in north Afghanistan provides increased medical and surgical treatment capability, focusing in emergency cases. The capabilities of the medical detachment and surgical squads are to provide life- and limb-saving surgery in the combat zone with subsequent hospitalization up to 48 hours with pre- and postoperative care of patients. Moreover, it provides care and treatment of acute illness, injuries or wounds in patients who are able to return to duty as soon as possible, emphasizing prevention as well as treatment of elective cases, mental health services, and occupational and preventive medicine. It is supported by Xray, mobile ultrasound, laboratory facilities, a two-bed intensive care unit, technicians, and blood supplies, which usually consist of up to 50 units of packed red blood cells (PRBCs). It also has the capability of administering initial resuscitation and stabilization of casualties in the field of action using ground ambulances, wheeled track vehicles and helicopters. Finally, it provides ward services for up to 15 patients under normal conditions, expanding to 25 patients in cases of mass casualties.

\section{The Deployment of the Surgical Team and Our Experience}

We performed triage, initial resuscitation, stabilization, and preparation of sick or injured patients for evacuation. We also provided consultation and medical and surgical services for locals, non-governmental organization personnel and ISAF patients. Despite the fact that some military hospitals refused to treat civilians for fear that some might be concealing bombs, we managed a large number of local patients (military staff and civilians).

Some days were quiet; others were overwhelming, where the surgical team had to manage more than three critically wounded patients. Lower-extremity shrapnel injuries, gunshot wounds to the stomach, liver and colon, shrapnel in the neck, chest, and back, extremity gunshot wounds, blast injuries, and burns were the most common cases. It was noticed that gunshots were the main mechanism of injuries for locals, whereas ISAF personnel usually presented with wounds after improvised explosive devices (IEDs), suicide bombs and rocket attacks.

Initially, the patients received first aid from a medic and two paramedics in the combat zone, and they were then transported by helicopter or vehicle to the hospital. On the arrival of the wounded patients, the standard Advanced Trauma Life Support (ATLS) protocol was carried out. Because of the high incidence of penetrating wounds, lifesaving operative management was frequently required. Our surgical strategy aimed for damage control. Definitive repair was performed if it could be done quickly. We packed off liver injuries for hemorrhage control, stapled off perforated bowel, placed a vascular shunt across injured vessels, provided temporary external fixation of fractures, washed out dirty wounds - whatever was necessary to stop bleeding and control contamination without allowing the patient to lose body temperature or become coagulopathic. In some cases, the abdomen was left open and vacuum-assisted closure was performed. We also performed serial operative washouts to ensure adequate removal of infectious debris.

Blast injuries from suicide bombs and IED attacks increased substantially and proved particularly difficult to manage. We often observed a combination of penetrating, blunt and burn injuries. Faced with the devastating injuries caused by IEDs, we had to preempt or reverse coagulopathy in patients who required massive transfusions. Blast injuries also produced an unprecedented burden of 'mangled extremities' limbs with severe soft tissue, bone and often vascular injuries. These could be devastating, potentially mortal injuries, and the decision of whether or not to amputate was one of the most difficult to make. Fasciotomies or escharotomies, rhabdomyolysis, and renal dysfunction were common in these wounded patients, a fact that required very careful and close monitoring. We also used fresh frozen plasma in a 1:1 ratio with PRBCs and recombinant factor VIIa (rFVIIa). ${ }^{[3]}$ This factor is an initiator of thrombin generation, which is used in trauma centers as part of a massive transfusion protocol. Recently, published combat injury data demonstrated a $20 \%$ reduction in PRBCs transfusions in patients who received $\mathrm{rFVIIa}{ }^{[4]}$

Our policy was to seek to limit surgery, and then the patients were transported by helicopter to the next level of care - at the role III German military hospital in the city of Mazaar-e Sharif - where more definitive surgery was performed. The most severely injured patients were transported by critical care air transport teams in large, fixed-winged planes to Germany, where they typically arrived within 24 to 36 hours of their injury.

As members of the military surgical team, we were forced to confront numerous unanticipated circumstances. The war continued far longer than planned, the volume of wounded soldiers increased, and the nature of the injuries changed. The needs facing the military medical personnel increased, while requests were made for additional staff members at all levels. Furthermore, as military surgeons in Afghanistan, we 
relied on civilian trauma criteria to guide our choices, but we think that these criteria did not prove reliable in this war, possibly because the injuries were more extreme or more often combined with multiple organ injuries.

\section{Lessons for the Future}

Deployments in crisis regions are currently one of the major factors influencing military medical service strategy planning. The aim of the treatment of sick and injured soldiers is to achieve an outcome that is equivalent to that which would be achieved by treatment in the homeland. The military surgeon must be aware of the specific aspects relevant to his work and the general aspects and strategies of the medical services. He should possess the necessary skills, knowledge, structure, and capacities of the medical facilities that will be available and be able to implement all lifesaving medical emergency measures for injured individuals.

It is essential that medical assistance be provided with the necessary speed. This means that the implementation of the organizational measures, the training of personnel and the provision of material resources including emergency transport capacity and transport equipment must ensure that the lives of the maximum possible number of casualties are saved. Under the special circumstances of crisis deployment, the aspects of speed and the consistency of the assistance provided with regard to the injury and to the strategic situation become highly important factors.

The materials required by a field surgical unit and a role II hospital near the combat zone differ from those used by a surgical department in the homeland. Furthermore, there are a number of peculiarities and limitations relating to the materials available due to the fact that all equipment (non-disposables) and materials (disposable) must be transported from the mother country. The problems present in this respect are mainly due to the limitation in transport capacity in terms of the long, time-consuming journey times. All the surgical materials should be appropriately designed and standardized, while military surgeons should have advanced training and qualification in order to be able to provide the services required using the materials provided.

Legal aspects and field transfusion medicine represent two other important factors under these special circumstances. There is a legal framework that must be observed during all activities. Rules-of-engagement and status-of-forces agreements can differ, depending on deployment locations, but the international law always forms the basis of all such documents, while for personnel on deployment abroad, the regulations that apply to health services in the mother country must also be followed. Field transfusion medicine differs from the techniques employed in the mother country. Although the decisive factors can be the number of blood bags and the spectrum of blood types available, the terms of reference are the same as those in the homeland.

All medical personnel and especially military surgeons should be properly trained, agile, skillful, and prepared for special aspects like polytrauma, mass casualty situations with triage, special field medicine requirements, and field hemostatic techniques. These special military medical skills must be specifically promoted and formed during the training of military medical personnel who are active in surgical fields abroad and especially under these difficult circumstances, as mentioned in our experience in the German military hospital in Kunduz. The processes of acquiring and teaching these skills should be carefully monitored.

Trauma training centers with carefully designed and planned programs in areas such as neurosurgery, pediatrics, urology, gynecology and obstetrics, and hygiene, and atomic, biological and chemical protection have to expose military surgeons to cutting-edge civilian concepts in trauma care. The special working conditions in war must also be presented. Emphasis should be placed on practical lessons, with the purpose to provide training in the specific surgical procedures appropriate to the life-threatening soft tissue trauma cases to be expected during these kinds of operations. Sufficient attention should also be paid to collaboration with adjacent disciplines, emergency treatment, anesthesia, and intensive care. Physicians from a variety of disciplines and a good level of specialist experience and teamwork skills are essential elements within a medical organization. In addition, these programs have to facilitate a dialogue between military and civilian trauma surgeons and improve clinical outcomes in the ongoing war in Afghanistan. These programs allow civilian trauma surgeons to participate in the care of injured soldiers by performing surgical procedures and directing intensive care.

Because of the high turnover of the deployed nurses and physicians working in this challenging environment, there is a need to develop standardized treatment guidelines. We think that the participation of registered nurses, critical care nurses, emergency department and surgical nurses as well as licensed practical nurses is necessary. They are required to be trained personnel in the resuscitative, surgical and perioperative management of patients, to administer drugs and blood products, manage ventilated patients, assist in surgical procedures, and occasionally to place body tubes.

We believe the following areas represent the major objectives of the training of military surgeons for deployment in war fields abroad: 
1. Specific skills for the management of lifethreatening trauma cases (burns, blast, gunshot, suicide, and IED injuries) in situations with limited resources.

2. Triage under mass casualty conditions.

3. Damage control surgery.

4. ATLS skills in combat situations.

5. Skills for the treatment of emergency cases in related fields (neurosurgery, pediatrics, urology, gynecology and obstetrics).

6. Experience of working in a mobile surgical task group and under combat conditions.

7. Knowledge of specific aspects of medical facilities, instruments and materials.

\section{References}

1. Central Intelligence Agency. World factbook: Afghanistan. (Accessed March 18, 2008, at https://www.cia.gov/library/ publications/the-world-factbook/geos/af.html.)

2. Borders R. Provincial reconstruction teams in Afghanistan: a model for post conflict reconstruction and development. J Dev Soc Transform 2004; 1:5-12.

3. Holcomb JB, Jenkins D, Rhee P, Johannigman J, Mahoney $\mathrm{P}$, Mehta $\mathrm{S}$, et al. Damage control resuscitation: directly addressing the early coagulopathy of trauma. J Trauma 2007;62:307-10.

3. Holcomb JB, Jenkins D, Rhee P, Johannigman J, Mahoney $\mathrm{P}$, Mehta $\mathrm{S}$, et al. Damage control resuscitation: directly addressing the early coagulopathy of trauma. J Trauma 2007;62:307-10.

4. Perkins JG, Schreiber MA, Wade CE, Holcomb JB. Early versus late recombinant factor VIIa in combat trauma patients requiring massive transfusion. J Trauma 2007;62:1095-1101. 